\title{
Physical violence cases in Pekanbaru, Indonesia: a 5 years retrospective study
}

Dedi Afandi

Faculty of Medicine, Universitas Riau

Correspondence:Dedi Afandi, dediafandi4n6@gmail.com

\begin{abstract}
Violence is a global public health problem. This study aims to identify the prevalence and patterns of injury among physical violence victims in Pekanbaru, Indonesia. Methods: A retrospective descriptive study was conducted at the Forensic Medical Service Center Bhayangkara Hospital Pekanbaru. All medicolegal reports of physical violence victims from January 1, 2010 to December 31, 2014 were studied for the prevalence of physical violence cases using basic data, such as sex, age, occupation, and forensic examination findings. Results: The average prevalence of sexual violence was $51.47 / 100,000$ population/year. The total number of cases was 5,206 , of which $75.7 \%$ were males. The 18-34-year-old age groups accounted for the highest proportion of cases for both genders. Bruises and abrasions were the most frequently found injuries ( $67.8 \%$ and $57.3 \%$, respectively), with the head being the most common injury sites. The majority of victims had blunt and mild degree of injuries (85.6\% and $83.8 \%$, respectively). Conclusions: the prevalence of physical violence cases was high among study populated. Although most of the victims had non-fatal injury but physical violence can affect all age group and both genders.
\end{abstract}

Keywords: forensic examination; pattern of injury; physical violence; prevalence

\section{Abstrak}

Kekerasan adalah masalah global kesehatan masyarakat. Penelitian ini bertujuan untuk mengetahui prevalensi dan pola luka korban kekerasan fisik di Pekanbaru, Indonesia. Metode: penelitian deskriptif retrospektif dilakukan di Pusat Pelayanan Forensik Rumah Sakit Bhayangkara Pekanbaru. Semua laporan medikolegal korban kekerasan fisik mulai 1 Januari 2010 sampai 31 Desember 2014 di-review untuk mendapatkan prevalensi kasus kekerasan fisik, dan hasil pemeriksaan forensik. Hasil: Rata-rata prevalensi kekerasan seksual adalah 51,47/100.000 penduduk/tahun. Jumlah kasus adalah 5.206, dimana $75,7 \%$ adalah laki-laki. Kelompok usia 18-34 tahun merupakan proporsi kasus terbanyak untuk kedua jenis kelamin. Memar dan lecet adalah luka yang paling sering ditemukan (masing-masing, $67,8 \%$ dan 57,3\%), dengan lokasi luka paling sering ditemukan pada daerah kepala. Mayoritas korban mengalami kekerasan tumpul dan derajat luka ringan (masing-masing 85,6\% dan 83,8\%). Simpulan: angka prevalensi kasus kekerasan fisik tinggi pada populasi penelitian. Meski sebagian besar korban mengalami luka non-fatal namun kekerasan fisik dapat ditemukan pada semua kelompok usia dan kedua jenis kelamin.

Kata kunci: kekerasan fisik; pemeriksaan forensik; pola luka; prevalensi 


\section{INTRODUCTION}

Violence is a global public health problem. Violence can lead to injury, health consequences, psychological disorders and death. Accurate estimates of the exact number of deaths and morbidity due to violence are difficult to determine, especially in cases of nonfatal violence. ${ }^{1}$ Violence also affects a country's economy because tackling this issue requires significant funding. A study in the United States reported that the overall cost of nonfatal injuries and deaths due to violence was more than $\$ 70$ billion, with an estimated $\$ 5.6$ billion needed for medical care in cases of intentional injury. ${ }^{2}$ Deaths caused by intentional injury between low/middle-income and high-income countries showed a similar proportion, but the number of deaths was higher in low/middle countries than in high-income countries. $^{3}$

In Indonesia, the latest data regarding intentional injury were obtained from the Ministry of Health (published in 2014), which revealed that physical injury due to blunt/sharp trauma ranked 4th in intentional injuries in Indonesia, with a total of $7.3 \% .{ }^{4}$ Physical violence is one of the natural acts of violence, but studies on physical violence are less popular than those on other forms of violence. However, more cases of physical violence occur daily than for any other form of violence. There is a lack of data regarding the prevalence of physical violence in hospital settings, especially in urban areas.
This study aims to identify the prevalence and pattern of injury of physical violence victims based on records from the Forensic Medical Service Center (FMSC) at Bhayangkara Hospital Pekanbaru (BHP). This hospital is a teaching hospital of the Faculty of Medicine, Universitas Riau and is the hospital centre for forensic medical services in Pekanbaru. All violence cases reported to the police are referred to BHP. Pekanbaru is the capital city of the Riau Province, one of the 34 provinces in Indonesia. This city is the third largest (inland) urban area on Sumatra Island, with a population of $1,011,467$ people. Pekanbaru is a heterogeneous city with 3 major tribes, namely, the Malay, Minang, and Batak.

\section{METHODS}

A retrospective descriptive study was conducted at the FMSC at BHP. The medicolegal reports of the physical violence cases referred by police investigators to the FMSC at BHP during a 5-year period starting from January 1, 2010 until the end of December 2014 were reviewed. The inclusion criteria for the physical violence cases were based on the medicolegal reports and the police's official inquiry letters. A case was categorized into a case of physical violence if the police's official inquiry letter contained article 351 or 352 of Indonesian Penal Code as the legal basis for the police to request a forensic medical examination. Official approval was obtained from the Director of BHP. Complete confidentiality 
was ensured throughout the study. Ethical approval was granted by the Institutional Ethics Committee of the Faculty of Medicine, Universitas Riau.

All medicolegal reports of physical violence cases were studied for the prevalence and patterns of injury. The prevalence and demographic characteristics included sex, age, and occupation. The pattern of injury based on forensic medical examination findings included the type, number and site of wounds; number of body regions; type of injury; and degree of injury. Determination of the degree of injury of physical violence among living victims was based on an interpretation from the Indonesian Penal Code and clinical judgment from a medical doctor. The degree of injury was classified as mild, moderate or severe. ${ }^{5-7}$

Table 1. Determination of the degree of injury of physical violence cases

\begin{tabular}{|c|c|c|}
\hline Degree of injury & Indonesian Penal Code & Interpretation \\
\hline Mild & $\begin{array}{l}\text { Article } 352 \\
\text { Except for Article } 353 \text { and } 356 \text {, maltreatment } \\
\text { that does not result in an illness or obstacle in the } \\
\text { performance of official or professional activities, } \\
\text { shall, as light maltreatment, be punished with a } \\
\text { maximum imprisonment of three months or a } \\
\text { maximum fine of three hundred rupiahs. }\end{array}$ & $\begin{array}{l}\text { If the wounds found on the victim } \\
\text { are minimal and can be cured by } \\
\text { themselves without medication; } \\
\text { injuries that do not require } \\
\text { medical treatment; does not } \\
\text { require hospitalization; total area } \\
\text { of bruises and abrasions less than } \\
47.2 \mathrm{~cm}^{2} \text {. }\end{array}$ \\
\hline Moderate & $\begin{array}{l}\text { Article } 351 \\
\text { Maltreatment shall be punished with a maximum } \\
\text { imprisonment of two years and eight months or } \\
\text { a maximum fine of three hundred rupiahs. }\end{array}$ & $\begin{array}{l}\text { Heavier wounds of a mild degree } \\
\text { but do not yet fulfill any of the } \\
\text { conditions in article } 90 \text {. }\end{array}$ \\
\hline Severe & $\begin{array}{l}\text { Article } 351 \\
\text { If the act results in a serious physical injury, the } \\
\text { offender shall be punished with a maximum } \\
\text { imprisonment of five years. } \\
\text { Article } 90 \\
\text { "Serious physical injury" denotes: illness or injury } \\
\text { that does not leave any prospect for a complete } \\
\text { recovery or through which danger of life exists; } \\
\text { continuous incompetence for performing official } \\
\text { and professional activities; loss of the use of a } \\
\text { sensory organ; mutilation; paralysis; disturbance } \\
\text { of the intellectual capabilities that lasts for more } \\
\text { than four weeks; and removal or death of the } \\
\text { womb of a woman. }\end{array}$ & $\begin{array}{l}\text { The circumstances of the injury } \\
\text { suffered by the victim fulfill one or } \\
\text { more conditions contained in } \\
\text { article } 90 .\end{array}$ \\
\hline
\end{tabular}

The collected data were analyzed statistically. For qualitative variables, a descriptive analysis was performed, and the results are presented as frequencies (percentages). The frequency of quantitative variables was calculated and represented by the mean \pm Standard
Deviation (SD) or median values if the data were not normally distributed. The chisquare test and other appropriate statistical tests were used to identify significant associations or perform comparisons between two qualitative 
variables. A p-value less than 0.05 was considered significant.

\section{RESULTS AND DISCUSSIONS}

Overall, the total number of medicolegal injury reports of living victims in the FMSC during the study period was 6,876 , and
$75.7 \%$ of those cases $(5,206)$ were identified as physical violence. The trend line of the number of physical violence victims increased over the years, with adults accounting for most of the physical violence victims and male victims outnumbering female victims in each of the study years.

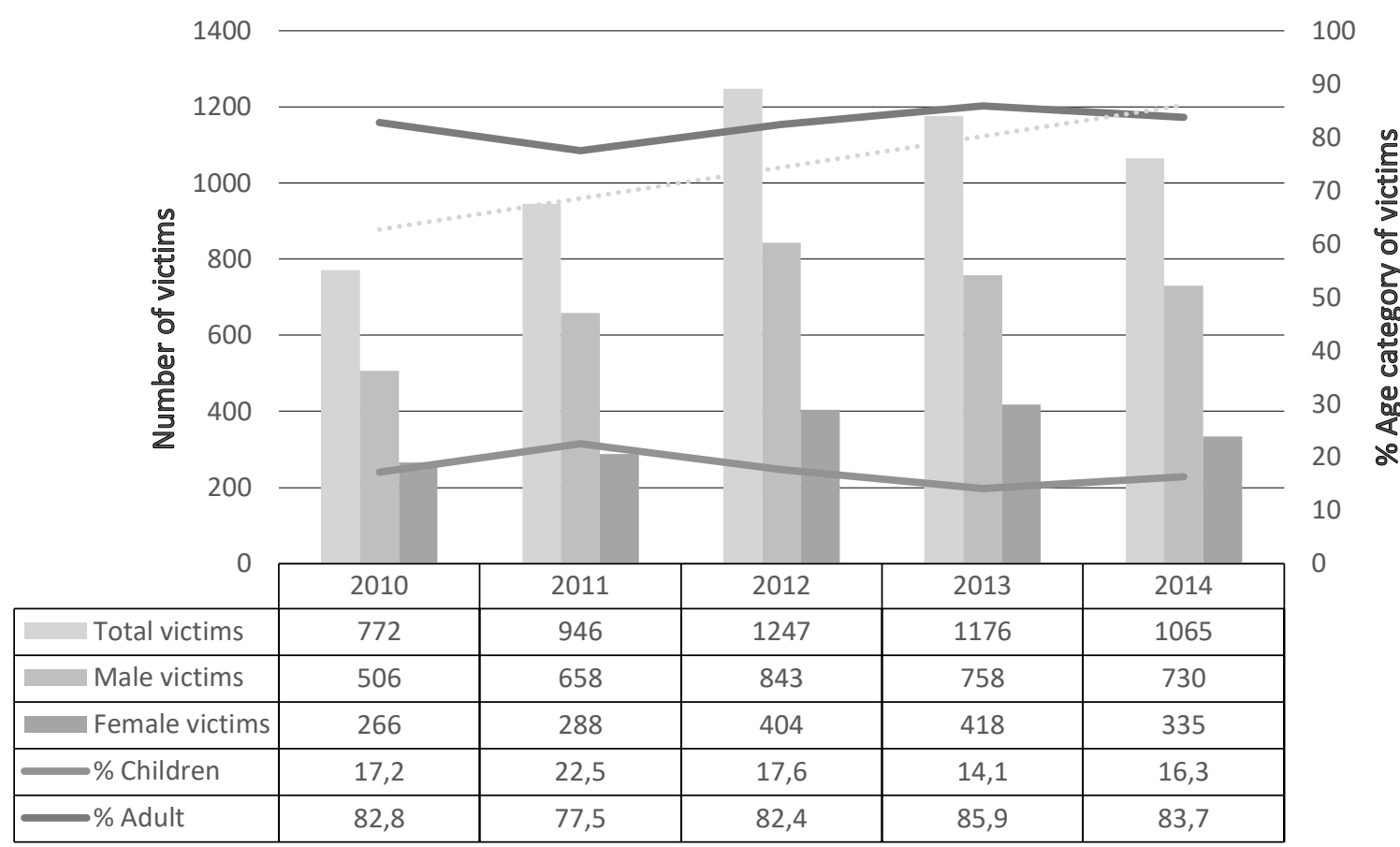

Trend line of the number of physical violence...

Figure 1. The number of physical violence victim cases, male and female victims and percentage of victims by age group per year

Data on cases of violence in hospital settings are required to supplement data from national surveys, as these data can provide actual information compared to surveys. ${ }^{1,8}$ The results of this study show an increasing trend of cases of physical violence across years. This is in line with the Global Burden of Disease study, which reported a $15 \%$ increase in intentional injury cases from 2005 to 2015 in 188 countries. ${ }^{9}$ The prevalence rate of physical violence cases in this study was $51.47 / 100,000$ population, which is much higher than the national prevalence rate of cases of physical violence in Indonesia. ${ }^{4}$ This difference can be explained by differences in study methods and the number of study samples. The increased number of violence cases in this study may be because, starting in 2012, our hospital 
waived the cost of examining victims of violence to create a medicolegal report. This can be considered a strategy to reduce the number of violence cases through information from the data collected.

Table 2. Association of age category and age group with gender in physical violence cases in Pekanbaru, Indonesia

\begin{tabular}{lcccc}
\hline \multicolumn{1}{c}{ Age } & Male & Gender & Total & p-value \\
& $\mathrm{n}(\%)$ & $\mathrm{n}(\%)$ & \\
\hline Age category & & $\mathrm{n}(\%)$ & & \\
Children & $706(20.2)$ & $199(11.6)$ & $905(17,4)$ & 0.000 \\
Adult & $2789(79.8)$ & $1512(88.4)$ & $4301(82.6)$ & 0.000 \\
Total & $3495(100.0)$ & $1711(100.0)$ & $5206(100.0)$ & \\
& & & & \\
Age group, year & $27.05 \pm 10.78$ & $29.37 \pm 10.57$ & $27.81 \pm 10.76$ & $13(0.2)$ \\
$0-4$ & $8(0.2)$ & $5(0.3)$ & $45(0.9)$ & $179(3.4)$ \\
$5-9$ & $30(0.9)$ & $15(0.9)$ & $667(12.8)$ & $1507(28.9)$ \\
$10-14$ & $148(4.2)$ & $31(1.8)$ & $1571(30.2)$ & \\
$15-<18$ & $519(14.9)$ & $148(8.6)$ & $795(15.3)$ \\
$18-24$ & $1061(30.3)$ & $446(26.1)$ & $316(6.1)$ & \\
$25-34$ & $982(28.1)$ & $589(34.4)$ & $86(1.7)$ & \\
$35-44$ & $471(13.5)$ & $324(18.9)$ & $27(0.5)$ & \\
$45-54$ & $195(5.6)$ & $121(7.1)$ & $5206(100)$ \\
$55-64$ & $67(1.9)$ & $19(1.1)$ & $13(0.8)$ & \\
$\geq 65$ & $14(0.4)$ & $1711(100.0)$ & \\
Total & $3495(100.0)$ & &
\end{tabular}

Physical violence cases are more prevalent than other cases of violence reported at the hospital. Our study shows that $75.7 \%$ of violence cases experienced physical violence. This finding is similar to those from other studies in Lahore-Pakistan, which reported that as many as $86.4 \%$ of 2166 medicolegal were cases of physical violence. ${ }^{10}$ However, studies in South Africa $^{11}$ and Tanzania ${ }^{12}$ reported much lower proportions of cases of physical violence, at $10.4 \%$ and $23.7 \%$, respectively. This difference was due to the studies in South Africa and Tanzania comparing cases of physical violence with all trauma cases, while in this study and studies from Pakistan, a proportional rate was obtained for medicolegal cases.
Table 2 illustrates the age and sex distributions of physical violence cases; specifically, $67.1 \%$ were males $(n=3,495)$, with a male-to-female ratio of $2: 1$. The mean age was 27.81 \pm 10.46 years, and there was a significant difference between males and females with respect to age $(p<0.001)$. The $25-34$ age group accounted for $30.2 \%$ of the total physical violence victims, while elderly victims aged $\geq 65$ years constituted only $0.5 \%$ of the total physical violence victims $(p<0.001)$. Most of the physical violence victims had irregular limited income work (56.2\%), and $3.9 \%$ of the physical violence victims were unemployed. 


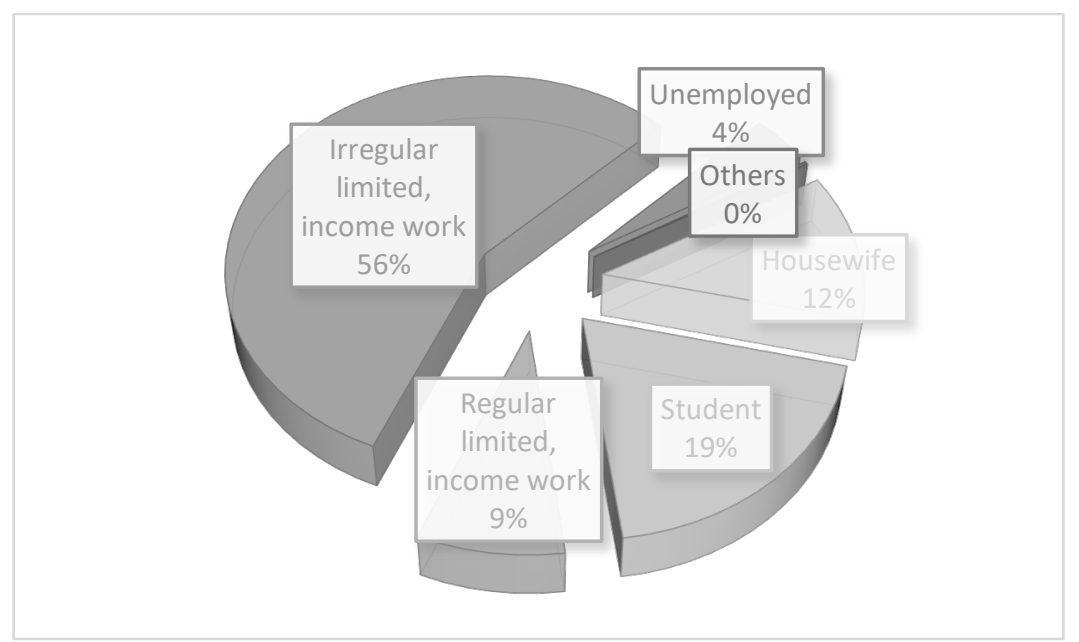

Figure 2. Distribution of cases according to the victim occupation

Males are more likely be victimized in cases of physical violence than women

These results were similar to those of other studies in Switzerland (56.6\%), LeratongSouth Africa (68\%), Brazil (72.8\%), India (74\%), KwaZulu-Natal, South Africa (81.3\%) and Pakistan (87.4\%), which reported that males were more likely to be victims than females. ${ }^{8,10,11,13-15} \mathrm{~A}$ study based on survey results in Iran also reported that males were the most common victims (66.7\%). ${ }^{16}$ This could be due to their active participation in risk-taking behaviours, greater activity outdoors, consideration of violence as an accepted strategy for resolving conflict, and the inherently more aggressive nature of males. ${ }^{11,12,14,17}$

In total, most victims were 25-34 years old. In females, most of the victims were in the same age group, but most of the male victims were found in a younger age group (18-24 years, $30.3 \%)$. When both groups were combined, the 18-34 age group represented the highest proportion of cases among both genders, wherein individuals aged $18-34$ were $58.4 \%$ of males and $60.5 \%$ of females and accounted for $43 \%$ of all physical violence victims. This is consistent with the results of studies from India and Pakistan. ${ }^{10,14}$ Victims in this age group will affect the national productivity and the economy; therefore, it becomes challenging for the government and related parties to implement preventive programs.

Of the total cases of physical injuries, $85.6 \%$ were caused by blunt injury, which agrees with the results of studies conducted in Pakistan, India, Brazil, and South Africa. ${ }^{8,10,11,14}$ Our study revealed that bruising was the most common type of injury $(67.8 \%)$, followed by abrasions (57.3\%). Similar results were also reported in studies in India, Nepal and Tanzania. ${ }^{12,14,17}$ A survey in Iran also reported that $50 \%$ of the wound types found were superficial wounds. ${ }^{16}$ In this study, there were no firearm wounds, as reported by the research from Pakistan and India. ${ }^{10,14}$ This can be explained by the tight regulations in Indonesia regarding the possession of firearms. 
Table 3. Association to the presence, number, site, type, and degree of injury with gender and age

\begin{tabular}{|c|c|c|c|c|c|c|c|c|}
\hline \multirow[t]{2}{*}{ Variable } & \multicolumn{2}{|c|}{ Gender } & \multirow{2}{*}{$\begin{array}{l}\text { Total } \\
\mathrm{n}(\%)\end{array}$} & \multirow{2}{*}{$\begin{array}{c}\mathrm{p}- \\
\text { value }\end{array}$} & \multicolumn{2}{|c|}{ Age category } & \multirow{2}{*}{$\begin{array}{l}\text { Total } \\
\text { n (\%) }\end{array}$} & \multirow{2}{*}{$\begin{array}{c}\mathrm{p}- \\
\text { value }\end{array}$} \\
\hline & $\begin{array}{l}\text { Male } \\
\mathrm{n}(\%)\end{array}$ & $\begin{array}{c}\text { Female } \\
\text { n (\%) }\end{array}$ & & & $\begin{array}{c}\text { Children } \\
\mathrm{n}(\%)\end{array}$ & $\begin{array}{l}\text { Adults } \\
\mathrm{n}(\%)\end{array}$ & & \\
\hline \multicolumn{9}{|l|}{ Type of wound } \\
\hline Bruise & 2310(66.1) & 1221(71.4) & $3531(67.8)$ & $0.000^{\mathrm{a}}$ & $612(67.6)$ & 2919(67.9) & $3531(67.8)$ & 0.887 \\
\hline Abrasion & $2052(58.7)$ & $929(54.3)$ & $2981(57.3)$ & $0.002^{\mathrm{a}}$ & $469(51.8)$ & $2512(58.4)$ & $2981(57.3)$ & $0.000^{\mathrm{a}}$ \\
\hline $\begin{array}{l}\text { Vulnus } \\
\text { laceratum }\end{array}$ & $462(13.2)$ & $94(5.5)$ & $556(10.7)$ & $0.000^{\mathrm{a}}$ & $66(7.3)$ & $490(11.4)$ & $556(10.7)$ & $0.000^{\mathrm{a}}$ \\
\hline Vulnus scissum & $123(3.5)$ & $24(1.4)$ & $147(2.8)$ & $0.000^{\mathrm{a}}$ & 15(1.7) & 132(3.1) & $147(2.8)$ & $0.020^{\mathrm{a}}$ \\
\hline Burn & $10(0.3)$ & $5(0.3)$ & $15(0.3)$ & 0.969 & $3(0.3)$ & $12(0.3)$ & $15(0.3)$ & 0.789 \\
\hline $\begin{array}{l}\text { Number of } \\
\text { wounds }\end{array}$ & $1.42 \pm 0.75$ & $1.33 \pm 0.68$ & $1.39 \pm 0.73$ & $0.000^{\mathrm{b}}$ & $1.29 \pm 0.72$ & $1.41 \pm 0.72$ & $1.39 \pm 0.73$ & $0.000^{b}$ \\
\hline None & $302(8.6)$ & $143(8.4)$ & $445(8.5)$ & $0.000^{\mathrm{a}}$ & $108(11.9)$ & $337(7.8)$ & $445(8.5)$ & $0.000^{\mathrm{a}}$ \\
\hline 1 wound & $1653(47.3)$ & $916(53.5)$ & 2569(49.3) & & $460(50.8)$ & $2109(49.0)$ & $2569(49.3)$ & \\
\hline 2 wounds & 1325(37.9) & $605(35.4)$ & 1930(37.1) & & $307(33.9)$ & 1623(37.7) & 1930(37.1) & \\
\hline 3 wounds & $201(5.8)$ & $40(2.3)$ & $241(4.6)$ & & $27(3.0)$ & $214(5.0)$ & $241(4.6)$ & \\
\hline 4 wounds & $14(0.4)$ & $7(0.4)$ & $21(0.4)$ & & $3(0.3)$ & $18(0.4)$ & $21(0.4)$ & \\
\hline Total & $3495(100.0)$ & $1711(100.0)$ & $5206(100.0)$ & & $905(100.0)$ & $4301(100.0)$ & $5206(100.0)$ & \\
\hline \multicolumn{9}{|l|}{ Site of wound } \\
\hline Head & $2562(73.3)$ & $1003(58.6)$ & $3565(68.5)$ & $0.000^{\mathrm{a}}$ & $615(68.0)$ & 2950(68.6) & $3565(68.5)$ & 0.710 \\
\hline Neck & $431(12.3)$ & $183(10.7)$ & $614(11.8)$ & 0.086 & $102(11.3)$ & $512(11.9)$ & $614(11.8)$ & 0.591 \\
\hline Chest & $276(7.9)$ & $126(7.4)$ & $402(7.7)$ & 0.499 & 70(7.7) & $332(7.7)$ & $402(7.7)$ & 0.987 \\
\hline Abdomen & $113(3.2)$ & $48(2.8)$ & $161(3.1)$ & 0.402 & $27(3.0)$ & $134(3.1)$ & 161(3.1) & 0.835 \\
\hline Back & $383(11.0)$ & 166(9.7) & $549(10.5)$ & 0.166 & $79(8.7)$ & $470(10.9)$ & $549(10.5)$ & 0.050 \\
\hline $\begin{array}{l}\text { Upper } \\
\text { extremities }\end{array}$ & $1041(29.8)$ & $771(45.1)$ & $1812(34.8)$ & $0.000^{\mathrm{a}}$ & $265(29.3)$ & $1547(36.0)$ & $1812(34.8)$ & $0.000^{\mathrm{a}}$ \\
\hline $\begin{array}{l}\text { Lower } \\
\text { extremities }\end{array}$ & $380(10.9)$ & $317(18.5)$ & $697(13.4)$ & $0.000^{\mathrm{a}}$ & $94(10.4)$ & $603(14.0)$ & $697(13.4)$ & $0.004^{\mathrm{a}}$ \\
\hline Genital & $3(0.1)$ & $0(0.0)$ & $3(0.1)$ & 0.555 & $0(0.0)$ & $3(0.1)$ & $3(0.1)$ & 1.000 \\
\hline $\begin{array}{l}\text { Number of body } \\
\text { regions with } \\
\text { wounds }\end{array}$ & $1.48 \pm 1.02$ & $1.53 \pm 0.96$ & $1.50 \pm 1.00$ & $0.000^{b}$ & $1.38 \pm 1.00$ & $1.52 \pm 0.99$ & $1.50 \pm 1.00$ & $0.000^{b}$ \\
\hline None & $302(8.6)$ & $143(8.4)$ & $445(8.5)$ & $0.000^{\mathrm{a}}$ & 108(11.9) & $337(7.8)$ & $445(8.5)$ & $0.000^{\mathrm{a}}$ \\
\hline 1 body region & $1929(55.2)$ & $852(49.8)$ & $2781(53.4)$ & & $504(55.7)$ & $2277(52.9)$ & $2781(53.4)$ & \\
\hline 2 body regions & $783(22.4)$ & $470(27.5)$ & $1253(24.1)$ & & $188(20.8)$ & $1065(24.8)$ & $1253(24.1)$ & \\
\hline 3 body regions & 299(8.6) & 180(10.5) & 479(9.2) & & $64(7.1)$ & 415(9.6) & 479(9.2) & \\
\hline 4 body regions & 132(3.8) & $51(3.0)$ & $183(3.5)$ & & $29(3.2)$ & 154(3.6) & 183(3.5) & \\
\hline 5 body regions & $35(1.0)$ & $13(0.8)$ & $48(0.9)$ & & $9(1.0)$ & $39(0.9)$ & $48(0.9)$ & \\
\hline 6 body regions & $11(0.3)$ & $1(0.1)$ & $12(0.2)$ & & $2(0.2)$ & $10(0.2)$ & $12(0.2)$ & \\
\hline 7 body regions & $4(0.1)$ & $1(0.1)$ & $5(0.1)$ & & $1(0.1)$ & $4(0.1)$ & $5(0.1)$ & \\
\hline Total & $3495(100.0)$ & $1711(100.0)$ & $5206(100.0)$ & & $905(100.0)$ & $4301(100.0)$ & $5206(100.0)$ & \\
\hline \multicolumn{9}{|l|}{ Type of injury } \\
\hline None & $302(8.6)$ & $143(8.4)$ & $445(8.5)$ & $0.001^{\mathrm{a}}$ & 108(11.9) & $337(7.8)$ & $445(8.5)$ & $0.000^{\mathrm{a}}$ \\
\hline Blunt injury & 2959(84.7) & $1496(87.4)$ & $4455(85.6)$ & & $741(81.9)$ & $3741(86.4)$ & $4455(85.6)$ & \\
\hline Sharp injury & $195(5.6)$ & $53(3.1)$ & $248(4.8)$ & & $49(5.4)$ & $199(4.6)$ & $248(4.8)$ & \\
\hline$>1$ type of injury & $39(1.1)$ & 19(1.1) & $58(1.1)$ & & $7(0.8)$ & $51(1.2)$ & $58(1.1)$ & \\
\hline Total & $3495(100.0)$ & $1711(100.0)$ & $5206(100.0)$ & & $905(100.0)$ & 4301(100.0) & $5206(100.0)$ & \\
\hline \multicolumn{9}{|l|}{ Degree of injury } \\
\hline None & $302(8.6)$ & $143(8.4)$ & $445(8.5)$ & $0.000^{\mathrm{a}}$ & 108(11.9) & $337(7.8)$ & $445(8.5)$ & $0.000^{\mathrm{a}}$ \\
\hline Mild & 2871(82.1) & $1493(87.3)$ & $4364(83.8)$ & & $746(82.4)$ & $3618(84.1)$ & $4364(83.8)$ & \\
\hline Moderate & $317(9.1)$ & $74(4.3)$ & $391(7.5)$ & & 50(5.5) & $341(7.9)$ & $391(7.5)$ & \\
\hline Severe & $5(0.1)$ & $1(0.1)$ & $6(0.1)$ & & $1(0.1)$ & $5(0.1)$ & $6(0.1)$ & \\
\hline Total & $3495(100.0)$ & $1711(100.0)$ & $5206(100.0)$ & & $905(100.0)$ & $4301(100.0)$ & $5206(100.0)$ & \\
\hline
\end{tabular}

${ }^{\mathrm{a}}$ Chi-square test; ${ }^{\mathrm{b}}$ Mann-Whitney $\mathrm{U}$ test, $\mathrm{P}$-values $\leq 0.05$ were considered significant

Most of the physical violence victims had fewer than 3 wounds (90\%; $p<0.001)$. The most common site of wounds was the head
(68.5\%), followed by the upper and lower extremities, at $34.8 \%$ and $13.4 \%$, respectively. This is in accordance with the 
results of other studies from India and Pakistan that reported that injuries of the head and neck were the most frequent for physical violence victims $\mathbf{1 5 5 . 4 \%}$ and 40.9\%, respectively). ${ }^{10,14} \quad$ The predominance of head and neck injuries was also reported by studies performed in Tanzania and Nepal. ${ }^{12,17}$ More than half of physical violence victims had 1 body region linked to the wound (53.4\%), while $0.1 \%$ of the total physical violence victims had 7 body regions linked to the wound. Wounds on the genitals were found only in adult males $(n=3,0.1 \%)$. Blunt injuries affected most of the total physical violence victims (85.6\%). Less than $10 \%$ of the total physical violence victims had no wounds $(p<0.001)$. Most physical violence victims had mild injuries (83.8), and there were significant differences between males and females and between children and adults with respect to the degree of injury (both $p<0.001)$. In general, the results of this study show that most of the victims had mild injuries. In the Indonesian legal system, determination of the degree of injury is one of the conclusions that doctors should write in a medicolegal report. This then serves as a basis for investigators, prosecutors, and judges to impose penalties on perpetrators. ${ }^{5,6,18}$
Our study has several limitations. This work was based on medicolegal reports of physical violence victims and contains only data relevant to justice and law enforcement. A retrospective study cannot analyze many other important variables. $A$ national violence survey with a representative sample of both public and private healthcare settings is recommended to provide the variables needed to thoroughly analyze the factors that lead to violence.

\section{CONCLUSIONS}

In conclusion, the prevalence of physical violence cases in victims in Pekanbaru was higher than the national prevalence rate in Indonesia, with most victims being adult males and a male-to-female ratio of 2:1. Bruising was the most frequent wound type, and the head was the most common wound site. Most of the physical violence victims had several wounds, and the number of body regions with wounds was predominantly less than 3 . Blunt and mild injuries were present in the majority of victims. Although most of the victims had non-fatal injury but physical violence can affect all age group and both genders.

\section{REFERENCES}

1. Krug E, Dahlberg L, Mercy J, Zwi A, Rafael L. World report on violence and health. Geneva: World Health Organization. 2002. P.2-21.

2. Corso PS, Mercy JA, Simon TR, Finkelstein EA, Miller TR. Medical costs and productivity losses due to interpersonal and self-directed violence in the United States. Am J Prev Med. 
2007; 32(6):474-82. doi: 10.1016/j.amepre.2007.02.010.

3. Hofman K, Primack A, Keusch G, Hrynkow S. Addressing the growing burden of trauma and injury in low- and middle-income countries. Am J Public Health. 2005; 95(1):13-17. doi: 10.2105/AJPH.2004.039354.

4. Indonesian Ministry of Health. Report of National Basic Health Research (RISKESDAS) 2013. Jakarta: Indonesian Ministry of Health; 2014.

5. Republic of Indonesia. Indonesian penal code (1946) [Internet]. Available from: https://www.unodc.org/res/cld/document/idn/indonesian_penal code html/l.1_Crimin al Code.pdf. Accessed: Desember 2017.

6. Afandi D. Visum et Repertum Perlukaan: Aspek Medikolegal dan Penentuan Derajat Luka. Maj Kedokt Indones. 2010; 60(4):188-95.

7. Afandi D. Total luas luka sebagai indikator penentuan derajat luka pada kasus medikolegal. J Indon Med Assoc. 2013; 64(3):129-33.

8. Gawryszewski VP, da Silva MMA, Malta DC, Kegler SR, Mercy JA, Mascarenhas MDM, et al. Violence-related injury in emergency departments in Brazil. Rev Panam salud pública. 2008; 24(6):400-8.

9. Vos T, Allen C, Arora M, Barber RM, Brown A, Carter A, et al. Global, regional, and national incidence, prevalence, and years lived with disability for 310 diseases and injuries, 19902015: a systematic analysis for the Global Burden of Disease Study 2015. Lancet. 2016; 388(10053):1545-1602. doi: 10.1016/S0140-6736(16)31678-6.

10. Arif M, Rasool SH. Physical injuries; Major cause of medicolegal cases reported to services hospital, Lahore. Prof Med J. 2017; 24(11):1727-1732.

11. Amashnee S, Guinevere G, Indiran G. Non-fatal injuries of interpersonal violence at the Leratong Provincial Hospital, South Africa. South African Fam Pract. 2016; 58(3):80-6. doi: 10.1080/20786190.2016.1167311.

12. Chalya PL, Gilyoma JM. The burden of intentional injuries in Mwanza City, North-Western Tanzania: A tertiary hospital survey. Tanzan J Health Res. 2012; 14(3):204-211.

13. Hofner MC, Burquier R, Huissoud T, Romain N, Graz B, Mangin P. Characteristics of victims of violence admitted to a specialized medico-legal unit in Switzerland. J Forensic Leg Med. 2009; 16(5):269-272. doi: 10.1016/j.jflm.2008.12.007.

14. Tingne CV, Shrigiriwar MB, Ghormade PS, Kumar NB. Quantitative analysis of injury characteristics in victims of interpersonal violence: An emergency department perspective. J Forensic Leg Med. 2014; 26(2014):19-23. doi: 10.1016/j.jflm.2014.06.003.

15. Lewis C, Wood D. Interpersonal violence as a major contributor towards the skewed burden of trauma in KwaZulu-Natal, South Africa. South African Med J. 2015; 105(10):827830. doi: 10.7196/SAMJnew.8380.

16. Salamati P, Rahimi-Movaghar A, Motevalian SA, Amin-Esmaeili M, Sharifi V, Hajebi A, et al. Incidence of self-reported interpersonal violence related physical injury in iran. Iran Red Crescent Med J. 2015; 17(3):e15986. doi: 10.5812/ircmj.15986. 
17. Subba SH, Binu VS, Menezes RG, Kumar V, Rana MS. Physical assault related injuries in Western Nepal - A hospital based retrospective study. J Forensic Leg Med. 2010; 17(4):203-208. doi: 10.1016/j.jflm.2010.02.001.

18. Gopalakrishnan H, Syukriani Y, Setiawati E. Forensic experts' opinion regarding clinical forensic medicine practice in Indonesia and Malaysia. J Forensic Sci Med. 2016; 2(2):8590. doi: 10.4103/2349-5014.184193. 